\title{
Potentiostatic Electrodeposition of Pt Nanoparticles on Carbon Black
}

$\operatorname{AUTHOR}(S)$ :

Miyake, Masao; Ueda, Takeshi; Hirato, Tetsuji

\section{CITATION:}

Miyake, Masao ...[et al]. Potentiostatic Electrodeposition of Pt Nanoparticles on Carbon Black. Journal of the Electrochemical Society 2011, 158(9): D590-D593

\section{ISSUE DATE:}

2011-07-19

URL:

http://hdl.handle.net/2433/237618

\section{RIGHT:}

(C) The Electrochemical Society, Inc. 2011. All rights reserved. Except as provided under U.S. copyright law, this work may not be reproduced, resold, distributed, or modified without the express permission of The Electrochemical Society (ECS). The archival version of this work was published in 'J. Electrochem. Soc. 2011 volume 158, issue 9, D590-D593'; の論文は出版社版でありません。引用の際には出版社版をご磪認じ利用ください。; This is not the published version. Please cite only the published version. 
Potentiostatic electrodeposition of Pt nanoparticles on carbon black

Masao Miyake, Takeshi Ueda, and Tetsuji Hirato

Graduate School of Energy, Kyoto University

Yoshida-hommachi, Sakyo-ku, Kyoto 606-8501, Japan

* Address correspondence to: Prof. T. Hirato

hirato.tetsuji.2n@kyoto-u.ac.jp

$+81-75-753-5432$

\section{Abstract}

Simple potentiostatic electrodeposition of platinum nanoparticles was performed on carbon black to prepare a carbon-supported Pt catalyst for polymer electrolyte fuel cells. The effect of ethylene glycol (EG) as an additive, deposition potential, and pH on the size and content of the electrodeposited Pt particles in the carbon powder was examined. Compared with the particles electrodeposited from a solution without EG, those with EG were smaller and dispersed well on the carbon. The electrodeposition at a more negative potential produced smaller particles. However, when the deposition potential was more negative than the equilibrium potential for $\mathrm{H}^{+} / \mathrm{H}_{2}, \mathrm{Pt}$ content higher than 30 wt\% could not be obtained. In contrast, when the deposition potential was more positive than the equilibrium potential of $\mathrm{H}^{+} / \mathrm{H}_{2}$, the Pt content could be controlled by the amount of electrical charge, and increased up to $40 \mathrm{wt} \%$. The electrodeposition from an alkaline solution yielded Pt particles with a mean 
size of $4 \mathrm{~nm}$, smaller than those obtained from a standard acidic solution.

Keywords

Platinum, Catalyst, Nanoparticles 


\section{Introduction}

The catalyst layer for polymer electrolyte fuel cells generally consists of carbon-supported Pt nanoparticles (1). As a support material, carbon black is employed extensively, although carbon nanotubes and nanofibers have also been investigated (2). To provide high catalytic activity with a small loading mass, the Pt particles need to be small and highly dispersed on the carbon support. A high content of $\mathrm{Pt}$ in the $\mathrm{Pt} / \mathrm{C}$ powder is also necessary to reduce the thickness of the catalyst layer.

Among the various methods to deposit Pt nanoparticles on carbon supports $(2,3)$, electrodeposition has the advantages of low-energy consumption and easy control of the loading mass of Pt. A variety of electrochemical techniques have been proposed, including potential step $(4,5)$, cyclic $(6)$, and pulse (7-11) electrodeposition from aqueous solutions containing $\mathrm{PtCl}_{6}{ }^{2-}$ or $\mathrm{Pt}\left(\mathrm{NH}_{3}\right)_{4}{ }^{2+}(12$, 13) with organic additives (14-17). The procedures and conditions for the electrodeposition have become quite complicated, and often seem to be of minor benefit in achieving both a small Pt particle size $(<5 \mathrm{~nm})$ and a high Pt content (> $30 \mathrm{wt} \%)$. Moreover, complicated processes often result in high costs.

In this study, simple potentiostatic electrodeposition was performed on 
carbon black from an acidic aqueous solution containing $\mathrm{PtCl}_{6}{ }^{2-}$ and ethylene glycol (EG) as an additive to elucidate the effects of EG and deposition potential on particle size and Pt content. Electrodeposition was also carried out from an alkaline solution to obtain smaller particles with a controlled Pt content.

2. Experimental procedures

\subsection{Electrodeposition}

Acidic and alkaline solutions for the electrodeposition of Pt were prepared by dissolving $38.6 \mathrm{mM}\left(=\mathrm{mmol} \mathrm{dm}{ }^{-3}\right) \mathrm{H}_{2} \mathrm{PtCl}_{6} \cdot 6 \mathrm{H}_{2} \mathrm{O}$ in a $0.1 \mathrm{M} \mathrm{H}_{2} \mathrm{SO}_{4}$ or $1 \mathrm{M} \mathrm{NaOH}$ aqueous solution. Unless otherwise noted, 0.5 M EG was added to all the solutions.

Carbon electrode was prepared from a commercially available carbon black (Ketjen Black EC). The carbon black (200 mg) was mixed with the above electrolytic solution $(10 \mathrm{ml})$ by a sonicator for 10 minutes, and the solution was naturally filtered with a funnel and filter paper (Watman, Grade 50, ф70 mm), leaving carbon paste on the filter. The paste was transferred onto a new sheet of filter paper and sandwiched by an additional filter sheet. The weight of the carbon in the transferred paste was about $170 \mathrm{mg}$. The rim of the sheets was folded so that the paste would not leak out during the electrodeposition. A Pt lead wire was inserted 
through a hole in the filter paper and attached to the carbon paste. The carbon paste and the filter paper was placed on the bottom of an electrolytic cell (100 ml) filled with the electrolytic solution $(25 \mathrm{ml})$ and used as a cathode.

Potentiostatic electrodeposition was carried out at room temperature with an electrochemical analyzer (ALS, model 660 C) using a porous carbon electrode and an $\mathrm{Ag} / \mathrm{AgCl}$ electrode immersed in a $3 \mathrm{M} \mathrm{NaCl}$ solution ( $0.227 \mathrm{~V}$ vs. SHE) as the counter and reference electrodes, respectively. All the potentials described in this paper are with respect to the $\mathrm{Ag} / \mathrm{AgCl}$ electrode.

After the electrodeposition, the carbon paste was washed in distilled water with sonication. The water containing the Pt/C powder was suction-filtered, and the powder recovered was dried at $60^{\circ} \mathrm{C}$ for 6 hours.

\subsection{Characterization}

The crystallinity of the $\mathrm{Pt}$ particles was examined by an X-ray diffractometer (XRD, Panalytical, X'Pert PRO-MPD) fitted with a copper X-ray tube $\left(\lambda_{\mathrm{Cu}}=0.1542 \mathrm{~nm}\right)$. The mean crystallite size of the Pt particles $(d)$ was estimated from the half bandwidth of 111 reflection $\left(b_{111}\right)$ at $2 \theta_{111}=40.0^{\circ}$ using Scherrer's equation, $d=0.9 \lambda_{\mathrm{Cu}} /\left(b_{111} \cos \theta_{111}\right)$. The morphology of the Pt particles on the carbon 
black was observed with a transmission electron microscope (TEM, Hitachi, H-9000NAR) operated at an accelerating voltage of $300 \mathrm{kV}$.

The amount of $\mathrm{Pt}$ in the carbon powder was determined by thermogravity analysis (TG, Shimadzu, TGA-51H). The measurement was carried out with $20 \mathrm{mg}$ of the $\mathrm{Pt} / \mathrm{C}$ powder using an alumina crucible in air. The powder was heated at $60^{\circ} \mathrm{C}$ for $10 \mathrm{~min}$ and $150{ }^{\circ} \mathrm{C}$ for $20 \mathrm{~min}$ to evaporate all water. The temperature was further increased gradually and held at $280{ }^{\circ} \mathrm{C}$ for $30 \mathrm{~min}$ to vaporize other impurities. The sample was then heated up to $600{ }^{\circ} \mathrm{C}$ to burn out the $\mathrm{C}$ powder, leaving the Pt powder. The weight loss of the powder in the temperature range between 280 and $600{ }^{\circ} \mathrm{C}$, and remaining weight at $600{ }^{\circ} \mathrm{C}$ was considered to be equal to the weights of $\mathrm{C}$ and $\mathrm{Pt}$ in the powder, respectively. The $\mathrm{Pt}$ content (\%) was determined by $(\mathrm{Pt}$ weight $) /(\mathrm{Pt}$ weight $+\mathrm{C}$ weight $) \times 100 \%$. The current efficiency for the Pt electrodeposition was derived from the Pt content, the weight of $\mathrm{C}$ powder used for the C electrode ( 170 mg), and the amount of electrical charge used for the electrodeposition.

The Pt/C catalytic electrode was made from the Pt/C powder as follows: 10 $\mathrm{mg}$ of the $\mathrm{Pt} / \mathrm{C}$ powder was mixed with $0.5 \mathrm{ml}$ of $5 \%$ Nafion dispersion solution (DE521, CS type) by a sonicator for 2 hours. The powder-containing Nafion solution 
$(1 \mu \mathrm{l})$ was loaded on a glassy carbon electrode and dried for a half day. The effective specific surface area of the Pt particles in the Pt/C electrode was estimated by hydrogen adsorption coulometry in a $0.1 \mathrm{M} \mathrm{HClO}_{4}$ aqueous solution at $40{ }^{\circ} \mathrm{C}$, assuming that the charge due to hydrogen monolayer adsorption on the Pt surface is equivalent to $210 \mu \mathrm{C} \mathrm{cm}-2 \mathrm{Pt}(18,19)$. The $\mathrm{HClO}_{4}$ solution was deaerated by $\mathrm{N}_{2}$ flow before the measurement.

3. Results and discussion

3.1. Effect of ethylene glycol

The electrodeposition of Pt particles on the carbon black was carried out at $-1.0 \mathrm{~V}$ in the acidic sulfate solutions containing $\mathrm{H}_{2} \mathrm{PtCl}_{6}$ with and without $0.5 \mathrm{M}$ EG. The EG was added to the solution with the expectation that smaller Pt particles would be electrodeposited (15, 16). The XRD patterns of the electrodeposited samples (Fig. 1) show that metallic Pt was electrodeposited from both the solutions with and without EG. The diffraction peaks of the sample deposited from the EG-containing solution are broader, indicating that smaller Pt particles were deposited with the addition of EG. The mean Pt crystallite sizes determined from the width of the Pt 111 diffraction peak with Scherrer's equation were about $5 \mathrm{~nm}$ 
and $8 \mathrm{~nm}$ for the samples from the solution with and without EG, respectively.

Figure 2 presents TEM images of the samples showing the electrodeposited Pt particles (black spots) on the carbon (gray areas). Although the TEM observation was carried out for many randomly chosen areas, Pt nanoparticles in the same size range were found almost everywhere in the same sample, suggesting that the electrodeposition of Pt nanoparticles occurred substantially uniformly on all over the carbon paste. The comparison of the TEM images clearly shows that the particles from the EG-containing solution are smaller than those from the solution without EG. The sizes of the Pt particles without EG range from 2 to $80 \mathrm{~nm}$, and with EG, 1-12 nm. Without EG, the particles shown in the TEM image look larger than the mean crystallite size determined by XRD $(\sim 8 \mathrm{~nm})$. A possible reason for this discrepancy is that the particles consist of smaller crystallites. On the other hand, the sizes of the Pt particles from the solution with EG shown in the TEM image are consistent with the mean size determined by XRD $(\sim 5 \mathrm{~nm})$, indicating that the deposited particles are well dispersed on the carbon. The deposition of well-dispersed Pt particles of a smaller size suggests that the EG molecules adsorb on the surface of the particles, suppressing the further growth and aggregation (15, 16). It might be concerned that the EG molecules adsorbed on the Pt particles could 
hinder the catalytic activity, but TG analysis confirmed that the EG molecules do not remain in the samples after washing with water, followed by drying at $60{ }^{\circ} \mathrm{C}$.

\subsection{Effect of deposition potential}

The effect of deposition potential was examined by performing the electrodeposition at $-0.2,-0.7$ and $-1.0 \mathrm{~V}$ in an acidic solution containing EG. As summarized in Table 1, the mean size of the Pt particles is independent of the amount of electrical charge for the electrodeposition, but tends to decrease slightly as the deposition potential becomes more negative. The electrodeposition at a more negative potential has the advantage of yielding smaller particles. However, the electrodeposition at -0.7 and $-1.0 \mathrm{~V}$ did not provide a Pt content exceeding $30 \mathrm{wt} \%$, even when the amount of charge was as large as $350 \mathrm{C}$, which theoretically gives a Pt content of $52 \mathrm{wt} \%$ if the current efficiency is $100 \%$. In contrast, the Pt content increased with the amount of charge and reached about $40 \mathrm{wt} \%$ at $-0.2 \mathrm{~V}$. The low $\mathrm{Pt}$ content at -0.7 and $-1.0 \mathrm{~V}$ is attributable to the evolution of $\mathrm{H}_{2}$ gas during the electrodeposition. Because the $\mathrm{pH}$ of the solution is about $1, \mathrm{H}_{2}$ gas theoretically would occur at potentials below $-0.29 \mathrm{~V}$ vs. $\mathrm{Ag} / \mathrm{AgCl}$. The $\mathrm{H}_{2}$ gas should evolve more vigorously on $\mathrm{Pt}$ particles than on carbon, because the overpotential for the 
generation of $\mathrm{H}_{2}$ gas is lower on $\mathrm{Pt}$ than on carbon. In fact, vigorous bubbling from the carbon electrode was observed for a period of time after electrodeposition at -0.7 and -1.0 V. The $\mathrm{H}_{2}$ gas in the carbon paste blocks the deposition of $\mathrm{Pt}$, and furthermore, the evolution of gas could cause the carbon paste to break and electrodeposited particles to drop off, leading to a decrease in the Pt content of the carbon powder. However, at $-0.2 \mathrm{~V}, \mathrm{H}_{2}$ gas does not occur, and therefore the $\mathrm{Pt}$ content steadily increases with the amount of charge.

\subsection{Electrodeposition from an alkaline solution}

As described above, the electrodeposition should be performed at a potential more positive than the equilibrium potential for $\mathrm{H}^{+} / \mathrm{H}_{2}$ in order to increase the Pt content beyond $30 \mathrm{wt} \%$. The electrodeposition at such a potential $(-0.2 \mathrm{~V})$ in an acidic solution, however, results in relatively large particles $(7-8 \mathrm{~nm})$. With the aim of depositing smaller particles with a high $\mathrm{Pt}$ content, the $\mathrm{pH}$ of the solution was changed from 1 to 14 by adding $1 \mathrm{M} \mathrm{NaOH}$ instead of $0.1 \mathrm{M} \mathrm{H}_{2} \mathrm{SO}_{4}$. In acidic solutions, the electrodeposition occurs via the following reaction (20):

$$
\mathrm{PtCl}_{6}{ }^{2+}+4 \mathrm{e} \rightarrow \mathrm{Pt}+6 \mathrm{Cl}^{-}
$$

In alkaline solutions, $\mathrm{Pt}$ ions are present in the form of $\left[\mathrm{Pt}(\mathrm{OH})_{6}\right]^{2-}$ and $\mathrm{Pt}$ would be 
electrodeposited by the reaction (21):

$$
\left[\mathrm{Pt}(\mathrm{OH})_{6}\right]^{2-}+4 \mathrm{e} \rightarrow \mathrm{Pt}+6 \mathrm{OH}^{-}
$$

The equilibrium potential for $\mathrm{H}^{+} / \mathrm{H}_{2}$ is $-1.05 \mathrm{~V}$ vs. $\mathrm{Ag} / \mathrm{AgCl}$ at $\mathrm{pH} 14$. Thus, the electrodeposition of $\mathrm{Pt}$ was carried out at $-1.0 \mathrm{~V}$ without generating $\mathrm{H}_{2}$ gas in the aqueous solution containing $38.6 \mathrm{mM} \mathrm{Pt}(\mathrm{IV}), 1 \mathrm{M} \mathrm{NaOH}$, and 0.5 M EG.

Figure 3 presents TEM images of the Pt particles deposited from the alkaline solution. Compared with those from the acidic solution (Fig. 2b), the particles from the alkaline solution are small (Fig. 3a). The magnified images clearly show the particles to be well dispersed on the carbon (Figs. 3b and c). These images also suggest that the increase in the amount of electrical charge increases the number of particles deposited, but not the size of the particles. The mean $\mathrm{Pt}$ crystallite size determined by XRD was $\sim 4 \mathrm{~nm}$ regardless of the electrical charge.

Figure 4 plots the Pt content of the carbon powder against the amount of electrical charge, including the results for the acidic solution. As mentioned above, in the acidic solution, the Pt content continued to increase together with the amount of charge at $-0.2 \mathrm{~V}$, but there was a limit to the Pt content at -0.7 and $-1.0 \mathrm{~V}$ because $\mathrm{H}_{2}$ gas evolves in these conditions. At $-1.0 \mathrm{~V}$ in the alkaline solution, the Pt content increased with the amount of electrical charge, owing to no $\mathrm{H}_{2}$ gas. A Pt content of 
$32 \%$ was obtained by the electrodeposition for $290 \mathrm{C}$. However, the increase in $\mathrm{Pt}$ content was lower in the alkaline solution at $-1.0 \mathrm{~V}$ than in the acidic solution at $-0.2 \mathrm{~V}$. The lower increase reflects a lower current efficiency for the electrodeposition of Pt. The dashed curve in Fig. 4 indicates the Pt content calculated assuming 100\% current efficiency. The current efficiency was 85-97\% at $\mathrm{pH} 1$ and $-0.2 \mathrm{~V}$, and 40-55\% at $\mathrm{pH} 14$ and -1.0 V. Possible side reactions include the reduction of dissolved oxygen, and hypochlorite ions generated at the anode. As shown in Fig. 5, the deposition current was much lower at $\mathrm{pH} 14$ and $-1.0 \mathrm{~V}$ than at $\mathrm{pH} 1$ and $-0.2 \mathrm{~V}$. The contribution of the side reactions to the total current is, therefore, greater at $\mathrm{pH} 14$, resulting in the lower current efficiency.

The $\mathrm{Pt} / \mathrm{C}$ catalytic electrodes were prepared from the $\mathrm{Pt} / \mathrm{C}$ powders in the conventional manner (22), and the effective specific surface area of the Pt particles in the electrodes was determined as a measure of catalytic activity. In Fig. 6, the surface area is plotted against particle size determined by XRD. The dashed curve shows the theoretical specific surface area of Pt spheres with a diameter of $d$. All values were consistent with the theoretical ones, indicating the Pt particles to be well dispersed on the carbon. Because the particles from the alkaline solution were smaller, they had a larger effective specific surface area, $560-690 \mathrm{~cm}^{2} / \mathrm{mg}-\mathrm{Pt}$. 


\section{Conclusions}

By simple potentiostatic electrodeposition, well-dispersed Pt nanoparticles could be obtained on the surface of the carbon black. The addition of EG to the electrolyte produced smaller particles. Although a more negative potential yielded even smaller particles, the Pt content of the carbon powder could not exceed $30 \mathrm{wt} \%$ when the potential was more negative than the $\mathrm{H}^{+} / \mathrm{H}_{2}$ equilibrium potential. When the potential was more positive than the $\mathrm{H}^{+} / \mathrm{H}_{2}$ equilibrium potential, the $\mathrm{Pt}$ content steadily increased with the amount of electrical charge and reached $40 \mathrm{wt} \%$. The particles deposited from the alkaline solution had a mean size of $4 \mathrm{~nm}$, and were smaller than the particles from the acidic solution. Although the current efficiency was as low as $50 \%$ in the alkaline solution, the Pt content could still be controlled through the amount of electrical charge.

\section{References}

1. S. Litster and G. McLean, Journal of Power Sources, 130, 61 (2004).

2. K. Lee, J. J. Zhang, H. J. Wang and D. P. Wilkinson, Journal of Applied Electrochemistry, 36, 507 (2006).

3. A. C. Chen and P. Holt-Hindle, Chemical Reviews, 110, 3767 (2010).

4. L. M. Plyasova, I. Y. Molina, A. N. Gavrilov, S. V. Cherepanova, O. V. Cherstiouk, N. A. Rudina, E. R. Savinova and G. A. Tsirlina, Electrochimica Acta, 51, 4477 (2006).

5. Y. Zhao, L. H. Fan, H. H. Zhong and Y. F. Li, Microchimica Acta, 158, 327 
(2007).

6. T. Huang, R. R. Jiang, D. Zhang, J. H. Zhuang, W. B. Cai and A. S. Yu, Journal of Solid State Electrochemistry, 14, 101 (2010).

7. Y. H. Qin, H. C. Li, H. H. Yang, X. S. Zhang, X. G. Zhou, L. Niu and W. K. Yuan, Journal of Power Sources, 196, 159 (2011).

8. J. J. Jow, S. W. Yang, H. R. Chen, M. S. Wu, T. R. Ling and T. Y. Wei, International Journal of Hydrogen Energy, 34, 665 (2009).

9. Y. Ra, J. Lee, I. Kim, S. Bong and H. Kima, Journal of Power Sources, 187, 363 (2009).

10. J. J. Li, F. Ye, L. Chen, T. T. Wang, J. L. Li and X. D. Wang, Journal of Power Sources, 186, 320 (2009).

11. H. S. Kim, N. P. Subramanian and B. N. Popov, Journal of Power Sources, 138, 14 (2004).

12. M. Verbrugge, Journal of the Electrochemical Society, 141, 46 (1994).

13. E. Taylor, E. Anderson and N. Vilambi, Journal of the Electrochemical Society, 139, L45 (1992).

14. J. M. Sieben, M. M. E. Duarte and C. E. Mayer, Materia-Rio De Janeiro, 15, 76 (2010).

15. M. C. Tsai, T. K. Yeh and C. H. Tsai, Electrochemistry Communications, 8, 1445 (2006).

16. J. M. Sieben, M. M. E. Duarte, C. E. Mayer and J. C. Bazan, Journal of Applied Electrochemistry, 39, 1045 (2009).

17. Y. J. Song, J. K. Oh and K. W. Park, Nanotechnology, 19, 6 (2008).

18. O. Antoine and R. Durand, Electrochemical and Solid State Letters, 4, A55 (2001).

19. T. Biegler, D. A. J. Rand and R. Woods, Journal of Electroanalytical Chemistry, 29, 269 (1971).

20. S. Dominguez-Dominguez, J. A. Pardilla, A. B. Murcia, E. Morallon and D. Cazorla-Amoros, Journal of Applied Electrochemistry, 38, 259 (2008).

21. J. Prabhuram and R. Manoharan, Journal of Power Sources, 74, 54 (1998).

22. S. D. Thompson, L. R. Jordan and M. Forsyth, Electrochimica Acta, 46, 1657 (2001). 
Table 1. Effect of potential on mean size and content of electrodeposited Pt particles in carbon black at pH 1 .

\begin{tabular}{ccccc}
\hline \multicolumn{2}{c}{ Condition for electrodeposition } & & \multicolumn{2}{c}{ Pt particles deposited } \\
\cline { 1 - 2 } \cline { 5 - 5 } $\begin{array}{c}\text { Deposition } \\
\text { potential (V) }\end{array}$ & $\begin{array}{c}\text { Amount of electrical } \\
\text { charge (C) }\end{array}$ & & $\begin{array}{l}\text { Mean Pt } \\
\text { particle size } \\
\text { (nm) }\end{array}$ & $\begin{array}{l}\text { Pt content } \\
\text { (wt\%) }\end{array}$ \\
\hline-1.0 & 120 & & 4.7 & 23 \\
-1.0 & 197 & & 5.5 & 28 \\
-1.0 & 354 & 5.5 & 16 \\
\hline-0.7 & 176 & 6.6 & 26 \\
-0.7 & 238 & 5.5 & 23 \\
\hline-0.2 & 140 & 7.6 & 28 \\
-0.2 & 274 & 7.1 & 41 \\
\hline
\end{tabular}

a: determined by XRD 
List of figure captions

Fig 1. XRD patterns of Pt particles electrodeposited on carbon black from an acidic solution containing (a) no EG and (b) $0.5 \mathrm{M}$ EG at $-1 \mathrm{~V}$.

Fig 2. TEM images of Pt particles electrodeposited on carbon black from an acidic solution containing (a) no EG and (b) 0.5 M EG at -1 V.

Fig 3. TEM images of Pt particles electrodeposited on carbon black from an alkaline solution containing $0.5 \mathrm{M}$ EG at $-1.0 \mathrm{~V}$ for (a and b) $150 \mathrm{C}$ and (c) 240 C. (b) is a magnified view of (a).

Fig 4. Pt content of Pt/C powder resulted by electrodeposition from solutions with pH 1 and 14 at various potentials. The dashed curve indicates theoretical Pt content assuming 100\% current efficiency for Pt electrodeposition.

Fig 5. Current for Pt electrodeposition in solutions with $\mathrm{pH} 1$ and 14 at various potentials.

Fig 6. Effective specific surface area vs. mean size of Pt particles electrodeposited from solutions with $\mathrm{pH} 1$ and 14 at various potentials. The dashed curve indicates the specific surface area of a Pt sphere with a diameter of $d$. 